\title{
CLASSIFICATION OF THE ACCOUNTING SYSTEMS: THE CASE
} OF DEFENSE EXPENDITURE.

\author{
Stylianou Tasos $1^{\text {st }}$ and Athianos Stergios $2^{\text {nd }}$
}

1, 2 Department of Accoynting and Finance, Technological Education Institute of Central Macedonia, Terma Magnisias, 62124, Serres, Greece, +302321049175, as@ teiser.gr

\section{ABSTRACT}

This In this paper clarify certain concepts, which are necessary to investigate the problems associated with defense spending and the defense industry of an economy. Defense spending includes all the money spent by a country on the maintenance of its armed forces and the amount spent for the operation of the defense sector of its economy.

These accounting expenditure measures are presented through a comparative theoretical study between.

The countries sum up different sets of funds to calculate the amount of their defense expenditure and there is no universal consensus on the exact definition of defense spending. As a result we have a differentiation of the accounting systems used by the countries to assess this item. Each country, depending on the classification of its accounting system, the organization of its service statistics and its external and defense policy considerations, applies different definition as the basis for calculating its defense expenditure.

Keywords: Accounting Systems, Classification, Defense Expenditure

IEL Classification: M40, M41, M49

Corresponding Author: Athianos Stergios

\section{INTRODUCTION}

Bogdan (2014) noted that the first attempts in order to classify the accounting systems are dated about a century ago. It was 1911 when Hatfield's classification was formed and it was consisted of three groups: USA, the United Kingdom, Northern Ireland and the continental Europe). The researcher's interest was increased in the decade of $60 \mathrm{~s}$. In the decade of $70 \mathrm{~s}$ emphasis was placed on the empirical grounding of the undertaken studies while in the 80s and 90s the most important part of international accounting research was constituted.

Nobes and Parker (2008) in an innovated research proposed a classification of the accounting systems using the taxonomy extrinsic (deductive) and intrinsic (inductive). The deductive approach implies that the classification of the accounting systems is based on the identification of the relevant environmental factors (legal system, tax system, culture, level of economic development, etc.). In the other hand, the inductive approach implies that the classification of accounting systems is based on the analysis of accounting practices.

1967 was the starting point of the deductive analysis of the accounting systems, where Mueller identified four development models for accounting systems such as macroeconomic, microeconomic, accounting as an independent discipline and uniform accounting (Tabără et al., 2010). The second important attempt to classify the Accounting Systems was made in 
1977 by AAA (American Accounting Association). It was an attempt to describe all the major characteristics which are influencing the accounting systems. Roberts et al, (2005) stated that the American Accounting Association identified eight influences called accounting system "parameters": political system, economic system, economic development, financial accounting objectives, the origins of accounting norms, education and accounting training, enforcement of ethical norms, the client (Roberts et al, 2005, pp.214-216). Based on this morphology, the American Accounting Association identified five influence zones: British, French-Spanish-Portuguese, German- Dutch, communist and American.

In his study Nobes (1988) pointed out that one of the most important factors to explain any difference among the accounting systems is the financing system which is varying from country to country. Hence, he divided the financial reporting systems into two classes. The first one is the "strong equity", in which we can find countries with strong funding through external equity, corresponding to the Anglo-Saxon systems such as United Kingdom and New Zeeland. The second class is the weal equity - outsider. In this class we can find countries with low equity corresponding to the continental Europe accounting systems (Nobes and Parker, 2008).

From the other hand, national defense represents all the productive factors that produce the national security asset and safeguard the territorial integrity and national independence of a country. The definition of the conceptual content of the national defense is therefore so easy, as the above definition gives us precisely both the identity and the functions that the defense sector performs in a society. However, the clarity of the defensive definition only provides us with a credible "photograph", a static picture of the elements that produce the good of security in a country. In economic science, however, static images, as reliable as they may be, do not provide meaningful help in analyzing the various socio-economic phenomena. In the case of defense, for example, the size and composition of security production factors can give us the "stigma" of the specific sector of the economy, but they do not provide us with the information that is necessary to understand the possible interconnections of defense, with other economic variables in the system. A comprehensive economic analysis of defense requires both the investigation of the key determinants of its size and the examination of its effects on certain critical financial items, such as fixed capital formation, expenditure on Education, Health and Welfare, the rate of economic growth development, etc. However, to analyze these problems, we must «quantify» the concept of defense; we must use a figure that represents the level of produced in a society, over a period of time.

In order to quantify the concept of defense, we need to assess the outcome of its operation, i.e the national security services it offers in a country. But the assessment of national security, presupposes the existence of a price, such as the operation of a market. The nature of defense as a public good does not allow for an objective determination of the aggregate demand curve of this good, which means that it is impossible to operate a market and it is unfeasible to set a price for national security. One could argue that the assessment of security services would be possible to some extent by assessing the overall social benefit of defense. However, the social benefit of defense includes all the benefits that society enjoys from the function of the defense sector. It is a figure that results from the enjoyment of national security, without even defining the value of the product that leads to the creation of the specific social benefit. Since we cannot estimate the value of security services, we still have to measure the cost of employing its productive factors and use the figure that will emerge as an approximate indicator of the level of defense. The total financial costs of employment of production factors of safety, is equal to the sum of funds spent by a country for the maintenance of the armed and lifeless material of its armed forces. This sum is the defense (or military) expenditure of an economy. 
The problem of assessing the security services that a country enjoys is not exhausted by assessing the defensive costs of its economy. Defense spending is an absolute figure that satisfies the level of defense produced in one country over a given period of time. However, this absolute figure cannot lead us to reliable conclusions when used to compare the levels of defense of different countries over the same period or the same country over different periods of time. So we need a relative number that expresses not only the level of defense but also its relative importance in the overall economic activity. For this purpose, the economists of defense are using the proportion of defense spending on the income of the economy the "Defense Burden" of the economy.

The analysis of the content and the problems of measuring the defensive costs and defense Burden of an economy are discussed below. More specifically, we examine:

1. The different definitions, hence the different ways of measuring defense expenditure,

2. The usefulness of the defensive Burden indicator in transnational or longitudinal comparisons, two or more levels of defense, and

3. The problems that arise in the defense weight measurement process.

\section{MATERIALS AND METHODS \\ LITERATURE REVIEW \\ DEFINITION AND METHODS OF MEASURING DEFENSE EXPENDITURE}

Defense spending includes all the money spent by a country on the maintenance of its armed forces, the amount spent for the functioning of the defense sector of its economy. What are these specific funds, which absorb each year a percentage of each country's budget? This question cannot be answered as a single answer, because the countries sum up different sets of funds to calculate the amount of their defense expenditure. In other words, there is no universal consensus on the exact definition of defense spending, and as a result we have a differentiation of the accounting systems used by the countries to assess this magnitude. Each country, depending on the classification of its accounting system, the organization of its statistical services and the considerations of foreign and defense policy, apply to calculate the costs of defense using one of the definitions adopted by the SIPRI (The Stockholm International Peace Research Institute), the US Department of Defense, and NATO. The components of defense expenditure according to these definitions are presented in Table 1.

TABLE 1: COMPONENTS OF DEFENSE EXPENDITURE ACCORDING THE DEFINITIONS OF SIPRI, NATO AND MINISTRY OF DEFENSE OF USA

\begin{tabular}{|c|c|c||}
\hline SIPRI & US DEFENSE MINISTRY & NATO \\
\hline \hline $\begin{array}{c}\text { Payments and Benefits in } \\
\text { Military Personnel Type. }\end{array}$ & $\begin{array}{c}\text { Payments and Benefits in } \\
\text { Military Personnel Type. }\end{array}$ & Expenditure on Military Staff \\
\hline $\begin{array}{c}\text { Payroll for Civilian } \\
\text { Personnel }\end{array}$ & & $\begin{array}{c}\text { Payments and Benefits to a } \\
\text { Type of Civilian Personnel. }\end{array}$ \\
\hline $\begin{array}{c}\text { Operation and } \\
\text { Maintenance }\end{array}$ & Operation and Maintenance & $\begin{array}{c}\text { Other Equipment, Supplies } \\
\text { and Operation (section). }\end{array}$ \\
\hline Supplies & Supplies & $\begin{array}{c}\text { Supplies of Main Equipment } \\
\text { and Missiles. }\end{array}$ \\
\hline Research and development & $\begin{array}{c}\text { Research and Development, } \\
\text { Auditing and Evaluation }\end{array}$ & $\begin{array}{c}\text { Other Equipment, Supplies } \\
\text { and Operation (section). }\end{array}$ \\
\hline Constructions & Military Constructions & $\begin{array}{c}\text { NATO Common Infrastructure } \\
\text { and National Construction }\end{array}$ \\
\hline
\end{tabular}




\begin{tabular}{|c|c|c|}
\hline Military Staff Pensions. & Military Staff Pensions. & Military Staff Pensions. \\
\hline Military Assistance & Military Assistance & \\
\hline Civil defence & & \\
\hline Paramilitary Forces & & \\
\hline $\begin{array}{c}\text { Military Elements of } \\
\text { Atomic Energy and Space }\end{array}$ & & \\
\hline & Family Housing & Other expenses \\
\hline
\end{tabular}

Source : G. Kennedy, " Defense Economics-, Duckworth 198 3, p . 50

SIPRI adopts the most general definition of defense expenditure, since it includes all the figures shown in the table, except that for family housing and "other Expenses", which include the recruitment costs and compensation payments to former military personnel ${ }^{1}$. The US Department of Defense recognizes as defense expenditure the elements of the previous definition, with the exception of civilian defense, paramilitary forces and military elements of atomic energy and space. The latter, although funded by the US Department of Defense, is not included in defense spending ${ }^{2}$. On the other hand, the payments of civilian personnel, although not shown separately in the table, are included in the "operation and maintenance" item. Finally, the NATO definition does not include the three elements mentioned above, as well as military assistance. Instead, in this definition as defense expenditure we consider recruitment costs and compensation payments to former military personnel, while R\&D expenditure appears on the figure "other equipment, supplies and operation".

The different definitions used to calculate defense spending create problems in comparing the defense budgets of different countries. It is worth to note that even the member countries of the Atlantic Alliance do not use the NATO definition but its various variants. For example, the United Kingdom, which applies this definition to a satisfactory degree, classifies its defense expenditure to personnel, equipment (sea, land and air) and other costs, as detailed in Table 2. The German's classification accounting system distinguishes its defense spending into operating and capital spending, but this classification is more of an adaptation of the NATO definition than a substantial differentiation from it. Regarding the Greek accounting system for the classification of defense expenditure, the budget of the Ministry of National Defense classifies the various funds, depending on the body or service that spends them. However, in the national accounts, the total amount of defense expenditure is divided into wages and benefits in kind of armed forces and military equipment and construction expenditure.

Problems in comparing the defense budgets of different countries are not only reflected by the different ways of measuring defense spending. Even assuming that all countries adopted the same definition, the sizes that would result every year, would not be directly comparable between them, because no definition of defense expenditure takes into account the fact that in some countries the engagement is voluntary and in others compulsory. While in the former case, the estimated defense size of defense expenditure represents the actual cost (the opportunity cost) of defense, in the latter case tends to underestimate these costs, since during the mandatory the military has much less earnings, than the average pay for work in the nondefense sector of the economy. A conclusion therefore, resulting from what has been said so

\footnotetext{
${ }^{1}$ The elements of the SIPRI definition presented in Table 1 are based on the definition of defense expenditure given by the SIPRI Yearbook 1973. However, in the SIPRI Yearbook 1988, the element of civil defense is excluded from the definition used by SIPRI to calculate defense spending in different countries.

${ }^{2}$ A. S. Becker (1977), "Military Expenditure Limitation for Arms Controls Problems and Prospects with a Documentary History of Recent Proposals", Cambridge , Mass
} 
far is that when comparing defense levels in different countries, we need to use data from the same source, ie calculated according to the same definition, and adjusted to reflect the size of the defense expenditures that would be spent by the comparing countries if they were implementing a system of volunteer engagement.

TABLE 2: SAMPLE OF THE BUDGET Of DEFENSE EXPENDITURE OF G. BRITAIN

\begin{tabular}{|c|c|c|}
\hline BUDGET FIGURES & EXPENDITURE & $\begin{array}{c}\text { PERCENTAGE OF } \\
\text { THE TOTAL }\end{array}$ \\
\hline \multicolumn{3}{|l|}{ Staff costs } \\
\hline Payments etc. of the Armed Forces & 2.845 & 20.2 \\
\hline Pensions of the Armed Forces & 657 & 4.6 \\
\hline Payments, etc. of the Civilian Staff & 1.829 & 13.0 \\
\hline \begin{tabular}{|c|} 
Partial Sum \\
\end{tabular} & 5.331 & 37.8 \\
\hline \multicolumn{3}{|l|}{ Equipment Costs } \\
\hline Marine & 1.913 & 13.6 \\
\hline Landfill & 1.285 & 9.1 \\
\hline Air & 2.795 & 19.8 \\
\hline Other Equipment & 551 & 3.9 \\
\hline Partial Sum & 6.545 & 46.4 \\
\hline \multicolumn{3}{|l|}{ Other expenses } \\
\hline Projects, Buildings and Earth & 805 & 5.7 \\
\hline Various Materials and Services & 1.410 & 10.0 \\
\hline Partial Sum & 2.215 & 15.7 \\
\hline Total & 14.091 & 100.0 \\
\hline
\end{tabular}

Source : Cmnd 8529. "Statement on

the Defense Estimates 1982" . vol. 2, Table 2.1. London : HMSO . 1982.

\section{PROBLEMS OF MEASURING THE DEFENSE WEIGHT OF THE ECONOMY.}

Let us assume that we want to compare the levels of defense enjoyed by two countries, A and

$\mathrm{B}$, over the same time period. For the analysis needs, we accept that:

1. Country A has a double area, population and productive resources from Country B,

2. The armed forces of the two countries use the same size of the same technology equipment and train the same number of military personnel with the same techniques of martial arts and

3. In both countries there is equal price of defense productive factors and a system of voluntary engagement is in place.

With this data, if we use any of the three definitions in Table 1, we will have as a result equal amounts of defense spending for the two countries. However, the same amounts of defense spending do not provide the same level of defense in different countries, as the consumption of equal quantities of any good, does not create the same level of prosperity in two populations of different size. In our hypothetical example, it is clear that the specific level of defense expenditure will provide more security in country B because in that country more defense units will be allocated to each unit of land, population and productive resources. The same reasoning also applies if we want to compare the levels of defense enjoyed by a country over two or more periods of time. As the size of the population and the quantity of the country's productive resources increase, the level of security that will be enjoyed by a certain 
amount of defense spending will be reduced, provided, of course, the stability of the prices of defense-producing factors over time. It is therefore clear that the absolute magnitude of defense spending is not a reliable measure for comparing the levels of defense of different countries over the same period or the same country over different periods of time. Long-term or transnational comparisons of different levels of defense must be based on a size that reflects both the cost of defense production and the level of security resulting from this particular cost of production. The basis of size must be the cost of defense, the absolute amount of defense spending, but it must be weighted by an indicator reflecting the particular population and economic conditions of each country. Because these conditions determine the wealth of a country, they are usually approached by the size of the annual income generated, reflecting the performance of this wealth. Thus, dividing the absolute magnitude of defense expenditures, with the size of the income generated by a country, results in a percentage reflecting the relative importance of national defense in the overall economic activity and giving the measure of releasing productive resources from the defense sector of the economy. Defense economists call this figure "Defense Burden" of the economy because it assesses the cost of defense according to the total economy output, depending on the potential of a country to finance the size of its defense expenditure.

The degree of reliability of the percentage of defense spending on income to determine the level of defense of a country depends on the degree of reliability of the measure of both defense expenditure and the income of the economy. For defense expenditure, the national accounts of each country record the monetary value of the total or a subset of the items included in one of the definitions in Table 1. However, in order to approximate the actual defense production costs, this size should be adjusted so that the individual funds express not only the corresponding financial costs but also the value of the output sacrificed as a result of the employment of various factors in the defense sector of the economy (ie the opportunity cost of defense). Similarly, the income of an economy satisfies the wealth of a country when it represents the total monetary value of the material goods and services produced in the country over a period of time. However, as organized the statistical service of a country could be, always there will be a part of the production activity that will be missing from the calculations. This section includes, on the one hand, those activities whose value cannot be measured (household production) and on the other hand, the "black economy", ie all transactions that escape from the taxation. So to arrive at a credible estimate of the annual output of a country, we need to take into account the official figures of its income and the size of its total black economy.

The problems that arise in the process of measuring the defense burden of an economy are not exhausted by assessing the opportunity cost of defense and taking the underground economy into account in the official size of the economy. In the literature, there is an inconsistency between defense economists about whether income and defense expenditure should be expressed at market prices or at factor prices. When the difference in subsidies from indirect taxes is not included in the data of the national accounts the variables are expressed in factor prices, reflecting the payments of the inputs rather than the actual final costs. In order for the percentage of defense expenditure on income to be a reliable indicator of the defense burden of a country, both variables should be expressed in the same form, ie at market prices or at factor prices. However, when this indicator is used to compare two or more countries' levels of defense, belonging to different economic systems, it is preferable that the relevant variables should be expressed at factor prices, since in the countries of formerly existing socialism the prices of products were defined in the context of the central planning of the economy, which greatly hampers the estimation of national accounts at market prices. On the other hand the comparisons of the defense levels of a country over different periods of time are indifferent to the form in which the levels of defense expenditure 
and income will be expressed, provided - of course - that during all time periods these variables will are expressed in the same form.

One other inconsistency in the literature is whether domestic or national product should be used in calculating the defense burden of the economy. While the domestic product of a country expresses the production within its territory, the national product expresses all production, including foreign assets. Because all of the arguments that are in favor or against the use of one or the other form of product are more technical than essential, the final decision in practice is usually given by the reliability of the available data of the two product types. All that we should have in mind is that the transnational or longitudinal comparisons of different levels of defense must be based on elements of defensive burden that have been assessed with the same form of product. However, in transnational comparisons, there is an additional problem, whether or not defense spending should be included in the income of the economy. Many countries are following the opinion of Kuznets ${ }^{3}$, who is arguing that defense spending is not a final product, but a kind of intermediate product that contributes to the production of the final product of the economy. According to this argument, defense spending should not be taken into account in the calculation of income because its size is included in the value of the final product of the economy. While the Western countries have not adopted this view, the national accounting practice of some former socialist countries (including the Soviet Union), stems from accepting the distinction of the product of an economy, productive and unproductive. In these countries, defense spending is considered as a non-productive product and is not included in the final income estimates. This difference requires the adjustment of the income figures of the eastern countries when they are used to calculate defense burdens and to compare their levels of defense with those of other Western countries.

The problems arising from the percentage of defense expenditure on income when used for longitudinal or transnational comparisons of different levels of defense have forced some economists to propose, as an alternative indicator for defensive burden measurement, the proportion of defense spending in total public spending ${ }^{4}$. However, this indicator complicates rather than simplifies the situation. For example, a country with high spending on Education, Health, Welfare, etc., will have a lower percentage of defense spending in total public spending than one other country with the same size of defense sector. In other words, any increase in the proportion of public spending on a country's income will cause an apparent reduction in the proportion of defense expenditure in public spending, even if the country's defense policy and strategic guidelines remain unchanged.

\section{CONCLUSION}

In order to examine the possible defense interfaces, with other economic variables of the economic and accounting system, it is necessary to use a size that reflects the level of security provided to a society over a period of time. Since the nature of defense as a public good does not allow the use of a market, and the setting of a price for the national security, economists use the cost of employment of defense productive factors as an approximate indicator of its level of production in a society. The monetary expression of these costs is the defense or military expenditure of an economy.

\footnotetext{
${ }^{3}$ S. Kuznets , (1948), "Discussion of the New Department of Commerce Income Series: National Income and New Version," Review of Economics and Statistics, vol. 30 , pp . 151 - 179.

4 See for example M. Leitenberg \& N. Ball, (1980) "The Military Expenditures of Less Developed Nations as a Proportion of their State Budgets" in the subject of A. Eide \& M. Thee, "Problems of Contemporary Militarism", London, p . 286-296.
} 
For the calculation of their defense spending, the countries are using different definitions and add different sets of funds, depending on the classification of their accounting systems and the feasibility of their foreign and defense policy. The most widely used definitions and classifications of accounting systems for the defense spending are those adopted by SIPRI, the US Department of Defense, and NATO. These definitions differ in some elements such as the cost of running civil defense and paramilitary forces, expenditure on military components of atomic energy and space, family housing costs and military and compensation of former military personnel. The different ways of measuring defense spending create a problem of comparability of the levels of defense of the different countries, which is becoming even greater due to the different systems of engagement and the particular population and economic conditions prevailing in each country. Thus, in quantifying the level of defense, we need a figure that, on the one hand, is based on its cost of production and on the other hand to be weighted with an index that expresses the particular population and economic conditions of each country. The percentage of defense expenditure on income fulfills these requirements, since it reflects the relative importance of defense in overall economic activity. This indicator is called defense burden of the economy because it assesses the cost of defense according to the potential of a country to finance its defense expenditure.

The percentage of defense expenditure on income adequately reflects the level of defense of a country when defense expenditure reflects the real cost of defense production and income represents the total monetary value of goods and services produced in the country. In other words, defense spending should reflect the opportunity cost of defense, while income must include all transactions that take place in both the formal economy and the underground economy. In the literature, there is an inconsistency between defense economists about whether the income and defense expenditure should be expressed at market prices or at factor prices, as well as whether the domestic or national product should be used, in calculating the defense burden of the economy. Because in both cases, the arguments that are in favor of one or the other aspect are more theoretical than substantive, the final decision in practice is usually dictated by the reliability of the available data. However, when the percentage of defense expenditure on income is used for transnational or longitudinal comparisons of different levels of defense, both defense spending and income should be expressed in the same format in all countries or all-time periods.

\section{REFERENCE}

[1] Becker, A.S., «Military Expenditure Limitation for Arms Control: Problems and Prospects, with a Documentary History of Recent Proposals», Cambridge, Mass., 1977.

[2] Bogdan, V., (2004) Armonizarea contabilă internaţională, Editura Economică, Bucureşti.

[3] Cmnd 8529. "Statement on the Defence Estimates 1982". vol. 2, Пívaкas 2.1. HMSO. 1982.

[4] Kennedy G., (1993), «Defense Economics», Duckworth, pp 50.

[5] Kuznets, S. (1948), «Discussion of the New Department of Commerce Income Series: National Income a New Version», Review of Economics and Statistics, vol. 30., pp. 151179. 
[6] Leitenberg, M. \& Ball, N. (1980), «The Military Expenditure of Less Developed Nations as a Proportion of their Slate Budgets», under A. Eide \& M. Thee, "Problems of Contemporary Militarism», London, p.p. 286-296.

[7] Nobes, G. (1988), A historical-comparative perspective of governmental accounting. In Ghan, J. E. and Jones, R. H. (Eds), Governmental Accounting and Auditing: International Comparison (Routledge, Eondon), pp. 198-206

[8] Nobes, C., Parker R., (2008), Comparative International accounting, Prentice Hall;

[9] Roberts, C., Weetman, P., Gordon, P, International Financial Accounting. A Comparative Approach, (Prentice Hall, 2005)

[10] SIPRI Yearbook 1973, Stockholm International Peace Research Institute, Oxford University Press, 1973.

[11] Tabără, N., Horomnea, E., Mircea M. C., (2010), Contabilitate Internaţională, Editura TipoMoldova, Iaşi, ediţia a 2-a; 